\title{
EchoGéo
}

48 | 2019

Illegal cannabis cultivation in the world

\section{Turning Cannabis Into Cash: Agrarian Change and Lesotho's Evolving Experience}

Julian Bloomer

\section{(2) OpenEdition \\ 12 Journals}

\section{Electronic version}

URL: https://journals.openedition.org/echogeo/17612

DOI: 10.4000/echogeo.17612

ISSN: 1963-1197

\section{Publisher}

Pôle de recherche pour l'organisation et la diffusion de l'information géographique (CNRS UMR 8586)

\section{Electronic reference}

Julian Bloomer, "Turning Cannabis Into Cash: Agrarian Change and Lesotho's Evolving Experience", EchoGéo [Online], 48 | 2019, Online since 13 July 2019, connection on 31 July 2021. URL: http:// journals.openedition.org/echogeo/17612 ; DOl: https://doi.org/10.4000/echogeo.17612

This text was automatically generated on 31 July 2021.

EchoGéo est mis à disposition selon les termes de la licence Creative Commons Attribution - Pas d'Utilisation Commerciale - Pas de Modification 4.0 International (CC BY-NC-ND) 


\title{
Turning Cannabis Into Cash: Agrarian Change and Lesotho's Evolving Experience
}

\author{
Julian Bloomer
}

1 Geographically, much of the scholarship on illicit drug cultivation and the political economic analysis of the global drugs trade has focused on the opium poppy and the production of heroin in Asia (Chouvy, 2010; Meehan, 2011; Chaves-Agudelo et al., 2015; Mansfield, 2016; Su, 2018) or on coca leaf cultivation and subsequent cocaine production in Latin America (Aviles, 2017; McSweeney et al., 2018; Muñoz-Mora et al., 2018). Estimates of the value of the global trade in drugs are notoriously difficult to calculate but some have suggested it may be equivalent to $8 \%$ of world trade (Hall, 2012). High value commodity chains and a focus on understanding the impact of Western driven policies, such as the war on drugs, has ensured the geographic focus lay largely beyond African shores, with the exception of the cannabis trade in Morocco (UNODC, 2004). In the past couple of decades, however, increased attention has focused on the cultivation and trade of illicit and 'quasi-legal' drugs across the African continent (Carrier and Klantschnig, 2012; African Union, 2013; Carrier and Klantschnig, 2018). The two principal plant-based drugs that have been researched are khat (Anderson et al., 2007) and cannabis (Carrier and Klantschnig, 2012) ${ }^{1}$. The former is culturally and geographically associated within a relatively confined area in east Africa, whereas the latter has been researched in various settings across the continent (UNODC, 2007), from Morocco (Chouvy and Macfarlane, 2018), to west Africa (Ellis, 2009; Suckling, 2016), to central Africa (Laudati, 2016), and southern Africa (Leggett, 2002; Kepe, 2003; Bloomer, 2009). Increased attention has also been paid to the geopolitical (Dimova, 2016), political economic (McCurdy and Kaduri, 2016), and development aspects (Bybee, 2012; Klantschnig et al., 2016; Carrier and Klantschnig, 2016) of the illicit drugs trade more generally on the continent.

2 Scholars who have been examining the role of illicit networks in today's global economy, have also been keen to highlight, however, that formal/informal, licit/illicit, 
legitimate/criminal often merge (Ferguson, 2006; Nordstrom, 2007). Legal status can vary both spatially and temporally. Irregular migrants, for example, can see their legal status fluctuate as they move through different territories (Tinti and Reitano, 2018). Similarly, a plant species like Cannabis sativa can be licit or illicit, depending where and when it has been produced - as Heyman (1999) said "legality and illegality are... simultaneously black and white, and shades of gray" (1999, p. 11).

3 This paper will briefly examine the history of cannabis cultivation and use in southern Africa before outlining its role as an illicit cash crop and significant livelihood strategy for smallholder farmers and vulnerable households in Lesotho (Bloomer, 2009). Against this background, the paper will analyse recent shifts in Lesotho's regulatory regime that saw the country make history in 2017 as the first African country to issue licenses for medical cannabis production (Khumalo, 2018). Yet the overall benefits to Lesotho's citizens of liberalising this aspect of the economy to foreign investment remain far from clear at this juncture, especially as a result of international and regional debates on policy reform and Lesotho's challenging economic position in the region.

\section{The political economy of cannabis in southern Africa}

4 The history of cannabis production in southern Africa is marked by at least four phases. The first phase involved the small-scale cultivation of cannabis to meet the needs of customs and rituals that saw tribal elders smoking cannabis but apparently in moderation (Magubane et al., 1975; Du Toit, 1996). The transition to the second phase, which is when cannabis was first cultivated as a cash crop, is harder to identify and varies within the region, but is likely to have been associated with the establishment and expansion of the migrant labour system and the expansion of a cash economy into rural areas of southern Africa. Life in single sex male compounds at remote mining locations and urban townships created a demand for substances such as alcohol and cannabis that could be paid for with the wages received (Du Toit, 1980). Cultivation in this second phase, however, was principally concerned with meeting demand in the region, and especially within South Africa, where alcohol and cannabis were the principal substances available due to the very limited supply and high cost of imported drugs, such as heroin and cocaine (Leggett, 2002). The third phase began in the early 1990s, coinciding with the fall of the apartheid regime in South Africa, as well as what had been a gradual decay of a formal migrant labour system. This period saw a reestablishment of legitimate trade within and outside of the region and consequently greatly facilitated the development of South Africa and the region as an international hub in drug trafficking. The fourth, and most recent phase, has seen the gradual legalisation of cultivation within the tight confines of medical cannabis production and export, with Lesotho leading the way (Rothberg, 2017).

5 Research that engages specifically with communities growing cannabis in the region remains very sparse and where it does occur has often been quite superficial. Eswatini, also known as the Kingdom of Swaziland, is a significant grower that supplies the South African and international markets, with over $70 \%$ of smallholder farmers in the northern Hhohho region alone growing cannabis for sale (Harrison, 2005). With such proportions of rural communities dependent on the cannabis trade, feasibility studies for alternative uses of cannabis are being creatively examined with proposals including a promotion of legal hemp production to replace declining cotton production (Hall, 
2003) to commercialising old traditions of brick making using a cannabis (hemp), lime and water mixture (IRIN, 2006).

6 South Africa maintains a longer record of observations. Du Toit $(1980 ; 1996)$ traces the early historical records of cannabis in Africa before embarking on a detailed survey of cannabis use amongst different ethnic groups in South Africa, making reference, inter alia, to the pre-1950s cannabis trade from Swaziland to South Africa. He notes many interesting observations on cannabis within South Africa, making the point that cannabis use is predominantly a male pastime, as well as highlighting the dilemmas between traditional and modern conceptions of cannabis use:

"Where the traditional system allows cannabis smoking and beer drinking as viable forms of social activity for mature adults, the modern government completely condemns cannabis. The modern system has also pressured the traditional lifestyle so that it is difficult to live even a marginal traditional life." (Du Toit, 1980, p. 94)

In the late 1970s, in a survey of rural South Africans, $9 \%$ admitted to resorting to extralegal activities such as selling alcohol without a licence and growing cannabis to meet household expenditures (Du Toit, 1980). More recently, Kepe (2003) highlighted the important role that social differences within rural communities play in determining who can successfully trade in cannabis in Pondoland in the Eastern Cape province. Lesotho has also been defined as a major international producer of cannabis (Gastrow, 2003), responsible for supplying other Southern African Development Community (SADC) countries, notably its neighbor South Africa. The extent to which cannabis from Lesotho travels beyond the continent through international drug smuggling networks is almost impossible to determine. Certainly, South Africa's infrastructure has allowed it to become a regional trafficking hub to Europe and elsewhere, as can be determined from seizures abroad (Oellermann, 2007; Schiller and Foy, 2017). The apparently poorer quality cannabis from Lesotho, however, may be largely restricted to the domestic market in South Africa.

Besides some of the more obvious difficulties that arise when individuals, households or communities depend upon extra-legal livelihood activities, three that are peculiar to the context of cannabis in southern Africa need to be discussed further. The most important of these is the claim that an increase in cannabis production will result in a decline in food crop production and consequently leave the region, already succumbing to perennial hunger, further depleted of its food reserves (Cilliers, 2001; Labrousse, 2003; INCB, 2004). In this case the short-term economic benefits of cannabis production may ultimately be detrimental to household security in the long run.

9 Another idea that has been developed in the literature is transnationalisation of criminal networks, namely in this context that South African cannabis smugglers were recruiting communities to grow cannabis. Thus, rather than local communities identifying a viable livelihood strategy, it may have been proposed and encouraged by outsiders, particularly syndicates of drug traders. Such control by syndicates would potentially affect price negotiations and the bargaining power of rural communities, both within South Africa and farther afield.

10 If local official collusion in the trade is present, this might suggest the presence of what Snyder and Duran-Martinez (2009) have referred to as state-sponsored protection rackets. These can occur if geographies of enforcement and criminality align in particular ways. Snyder and Duran-Martinez (2009) also examine the relationship between illegality and violence and highlight how it varies both temporally and 
geographically and indeed highlight that there is no clear line between the licit and illicit. This is important to consider in the context of Lesotho, which has continued to experience weak governance and troubling undercurrents of political conflict and domestic violence (Goeke, 2016; Mwangi, 2016; Adams and Nkuebe, 2018; Pherudi, 2018), although the explicit role of illicit markets in this mix is hard to quantify. In a similar vein, Suckling (2016) discusses the concept of criminalisation of the state in the context of the cannabis trade in Sierra Leone, however, the role of migrant Rastafari cannabis farmers from Jamaica has also seen a transfer of knowledge and skills there.

11 South Africa's dominant position in the region, as a financial and trade hub, functions for both the licit and illicit trade networks in a similar manner (Carmody, 2011). South Africa can export its own industrially produced food crops, for example, whilst importing cannabis from surrounding countries, especially Lesotho and Swaziland. As is examined later in the paper, policy relating to cannabis production is evolving at a rapid rate in recent years and this places Lesotho in a difficult position as any competitive advantage is likely to be lost once South Africa legalises production.

Laniel (2001) noted how drugs are "well-suited to play the role of 'hard currency': they are fairly cheap to produce, command a high sale price, are not subject to inflation... and they can either be disposed of, for cash or other goods, on a growing regional consumer market or used in other regional or international transactions" (2001, p. 411). A commodity-chain approach, therefore, can be a valuable instrument to follow both the physical distribution of the commodity but more importantly to ascertain how the value of the commodity changes, generally increasing from the point of production to the point of consumption, although the fluidity of the current situation must be borne in mind. On a political note, it is also crucial to bear in mind the motivations of politicians and security forces in enforcing laws on cannabis prohibition, a crop that clearly brings much income to rural communities who are coping with the collapse of the formal migrant labour system, and who now languish amidst declining food crop yields and have very few employment opportunities.

\section{A history of cannabis in Lesotho}

In the opening to A Short History of Lesotho, Gill (1993) alludes to the important role that cannabis may have played during the period of Sotho settlement in present day Lesotho. The San and their ancestors had been hunting and gathering in the region for thousands of years; their pictorial depictions of eland and other animals that roamed the region at the time are still visible on rock faces in Lesotho today. The gradual expansion of the Sotho and their mixed economy of crop farming, herding and hunting over the past three or four centuries, however, reduced the land available to the San. While some Sotho clans apparently employed methods, such as intermarriage, to forge allegiances with the San, other clans "such as the koena, have passed down oral traditions which display a rather patronising and 'colonial' mentality of how they 'bought' San land for a supply of dagga" (Gill, 1993, p. 7). Such an occurrence would point not only to the cultivation of cannabis, but also to the existence of trade networks in cannabis as having been present for the past two or three centuries at least, and may have been a facilitating factor in the shift from a nomadic, hunting-and-gathering San to the more pastoral and agriculturally focused Sotho, when the cultivation of cannabis may have encouraged more permanent settlements to emerge. 


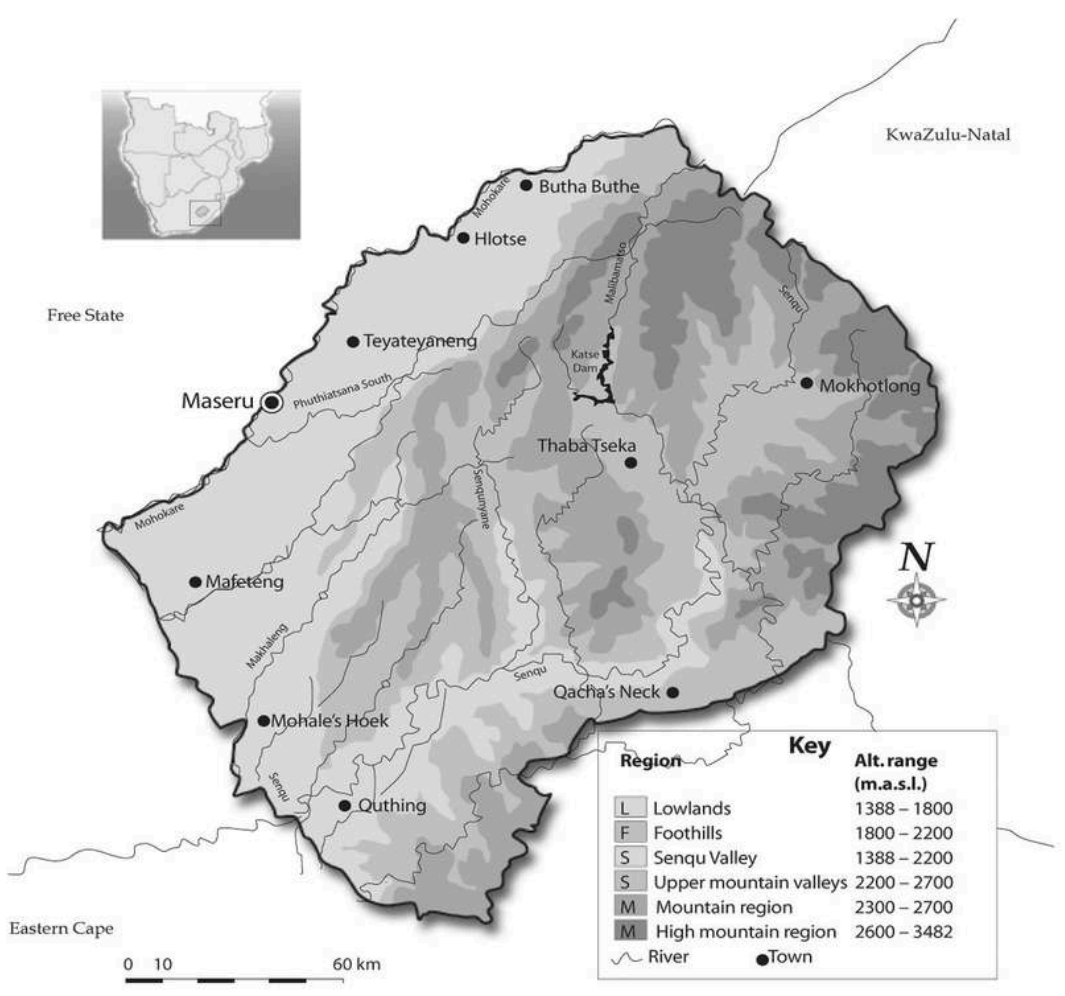

Adapted from Kobisi (2005).

One of the difficulties with a historical analysis of the literature from this period is the scarcity of available records. Even when written records become more widespread, especially when Lesotho became a protectorate under the colonial wing of Britain from 1868 , there is little mention of the various crops that were planted. In later years, following international criminalisation of cannabis in 1925, colonial records focus on legitimate transactions for the purpose of taxation rather than illegitimate activities. Early proselytisers in Lesotho remain one of the main literary sources of information on Basotho life, written from the perspective of a missionary. Casalis (1889) notes that "in contrast to tobacco, the Basotho confess that the use of dagga, is much more ancient" $(1889$, p. 141). Aside from its use in cultural settings cannabis was also a food supplement (Guillarmod, 1971).

Most historical and ethnographic writings of the early twentieth century on the Basotho make only passing references to cannabis (for example, Ellenberger and MacGregor, 1912; Ashton, 1967) and focus almost exclusively on methods of smoking rather than, for example, the extent of cultivation. Only in much more recent times have the production and consumption of cannabis featured in greater detail in the literature.

\section{The economic importance of cannabis}

By the mid-1980s, Gill (1993) notes, probably very conservatively, that "hundreds of enterprising farmers, unable to make ends meet and in need of a hearty cash crop which could withstand Lesotho's variable climate, turned to the growing of dagga 
which has become (unofficially) Lesotho's most lucrative cash crop" (1993, p. 236). It was not until the mid-1990s that information on cannabis production began to appear in writing in the preparation studies for the second phase of the Lesotho Highlands Water Project (LHWP), one of the most ambitious engineering projects ever to take place on the African continent. The purpose of the LHWP was to place several dams in the Lesotho highlands, capturing the relative abundance of water in the area and by means of transfer tunnels and channels, supply the Gauteng urban region in South Africa that includes the two cities of Pretoria and Johannesburg. Lesotho would then receive payment from South Africa for the water and a hydro-electric generator would meet the majority of Lesotho's electricity demands, as well as provide additional revenue from energy exports to South Africa.

Large-scale dams have invited a lot of criticism in recent years in many regions of the world, such as the infamous Narmada dam in India (Baviskar, 2004) and the Three Gorges in China (Heggelund, 2004). One of the principal arguments put forward by opponents of these large dams is that the social costs of displacing communities when their lands are flooded outweigh the benefits of large-scale dams. Other arguments focus on the ecological impact of such dams as well as their safety and suitability (Scudder, 2006). The erection of the dams at Katse and Mohale in Lesotho has also received criticism, particularly in the face of changing climate patterns that have been experienced in recent years in the region (Braun, 2015; Kings, 2016; Hoag, 2019).

In order to establish the parameters for the compensation to be given to households that were to be resettled, a detailed survey of livelihoods and incomes in the affected areas was undertaken. By the mid-90s Katse dam, the first phase of the LHWP, was nearing completion but the reports from Phase 1A (Katse) did not allude to cannabis production in the area. In one survey from Phase 1B (Mohale), however, it was noted that: "marijuana production in both the Phase $1 \mathrm{~A}$ and Phase $1 \mathrm{~B}$ areas is reported to be an important source of income for many households" (LHWP, 1996a, p. 19). The report went on to note that "because of the illegal nature of this crop, it is extremely difficult to measure the contribution it makes to the standard of living of people but it undoubtedly has had an impact" (LHWP, 1996a, p. 19).

It is interesting to note that these references to cannabis were appearing in the LHWP surveys that were examining baseline epidemiology and medical services (LHWP, 1996a; 1996b), rather than in the context of a livelihoods or socio-economic report. A survey for Phase $1 \mathrm{~B}$ revealed that $34.4 \%$ of households sold cannabis in comparison with $29.6 \%$ selling joala (home-brewed alcohol made from sorghum) and $3.3 \%$ who received an income from selling commercial beer (LHWP, 1996b, p. 95). When the mean monthly incomes from these products were calculated, the two categories of marijuana and alcohol brought in nearly $70 \%$ of households income.

19 Although the practicalities of getting a World Bank funded project to compensate farmers for the loss of revenue from illegal crops were not discussed, a third LHWP report stated that:

"Marijuana is currently estimated to be cultivated on $10 \%$ of the arable land and accounts for $60 \%$ of the arable crop net revenue. Cash payment would therefore have to acknowledge this, if the principle of maintaining the incomes of people whose lives are disrupted is to be maintained." (LHWP, 1996c, p. 57)

The authors of the report went on to propose compensation that would combine the loss of income from grains (such as maize, sorghum and wheat) as well as for cannabis 
based on a total one-hectare plot (LHWP, 1996c, p. 57). Under this proposed compensation scheme almost one-third of the monies given to compensate for loss of income and food crops would have been solely for cannabis.

An environmental impact assessment report produced the following year for the same area estimated that cannabis was grown by about $70 \%$ of farmers (LHWP, 1997, p. 4-52). This represents a very large discrepancy with the report just mentioned, which found $34.4 \%$ of households selling cannabis, especially since only $18.9 \%$ of male respondents claimed to have ever smoked cannabis (LHWP, 1996b, p. 96), so the difference cannot be explained by domestic consumption. The report, however, also estimated yields of approximately 100 kilograms of cannabis per hectare (LHWP, 1997, p. 4-54), although the estimate is low according to Leggett (2006, personal communication, email), who believes a hectare of cannabis in Lesotho should yield around 1 MT of saleable product based on fieldwork in the South African provinces surrounding Lesotho.

Oral testimonies from the members of the affected communities at Mohale were gathered prior to the informants' resettlement (Panos, 1997). These testimonies provide an insight as to the likely impact of resettlement on livelihoods. Over half of the interviewees discussed how they grew and sold khomo ea fats'e (literally 'the cow of the ground' - cannabis) and what an important part of their livelihood portfolio it was:

"People always come here to buy cannabis from us, and it helps us a lot because with it we are able to pay our children's school fees and maintain our families. Cannabis is really important to us. Even during Christmas our children are able to have new clothes, such that an outsider may even think we are employed." (Thabang, male, age 57, farmer. In Panos Institute, 1997)

Also evident from the interviews are the concerns that people had with regard to how their livelihood strategies might change following resettlement, with the majority moving to the much more densely populated lowlands. Cannabis was such an important aspect of their livelihood portfolio that whether or not they could continue to cultivate "greatly influenced some of the resettlee's choice of new homes" (Thabane, 2000, p. 638), such as Moleleki's view:

"I am looking at whether there are a lot of fields. They are many, even though they do not do anything, because people just live on cannabis. I am just looking whether there is a place where I can sow tobacco on top of the plateaus there." (Moleleki, male, age 41, farmer. In Panos Institute, 1997)

It is very difficult to establish accurately the importance of cannabis production as a livelihood strategy and the geography of its cultivation in Lesotho. While it does show up in the nationwide livelihood surveys, estimates of the percentage of households growing cannabis are undoubtedly grossly underestimated due to non-disclosure. Gay and Hall (2000), for example, found that $1.5 \%$ of households were involved in selling cannabis, although such national estimates hide the fact that cannabis growing is concentrated in pockets of mass production around the country. Turner (2001) makes the prescient comment that "the most lucrative cash crop of all, dagga [cannabis], shows up in the livelihood strategies of the whole spectrum of rural households. Legalisation of the herb in South Africa could be catastrophic for Lesotho livelihoods" (2001, p. 95). According to Laniel (1998), the main areas of cannabis production in Lesotho are the high mountain zones in the centre and east of the country, as well as in the western foothills region and in the Senqu River valley. Within one small community in the foothills, field surveys and household income analysis found that up to $39 \%$ of 
the total field area in the village was planted with cannabis and $28 \%$ of the village's income came from the sale of cannabis (Bloomer, 2009).

Illustration 2 - Dried leaves and seeds from Cannabis sativa

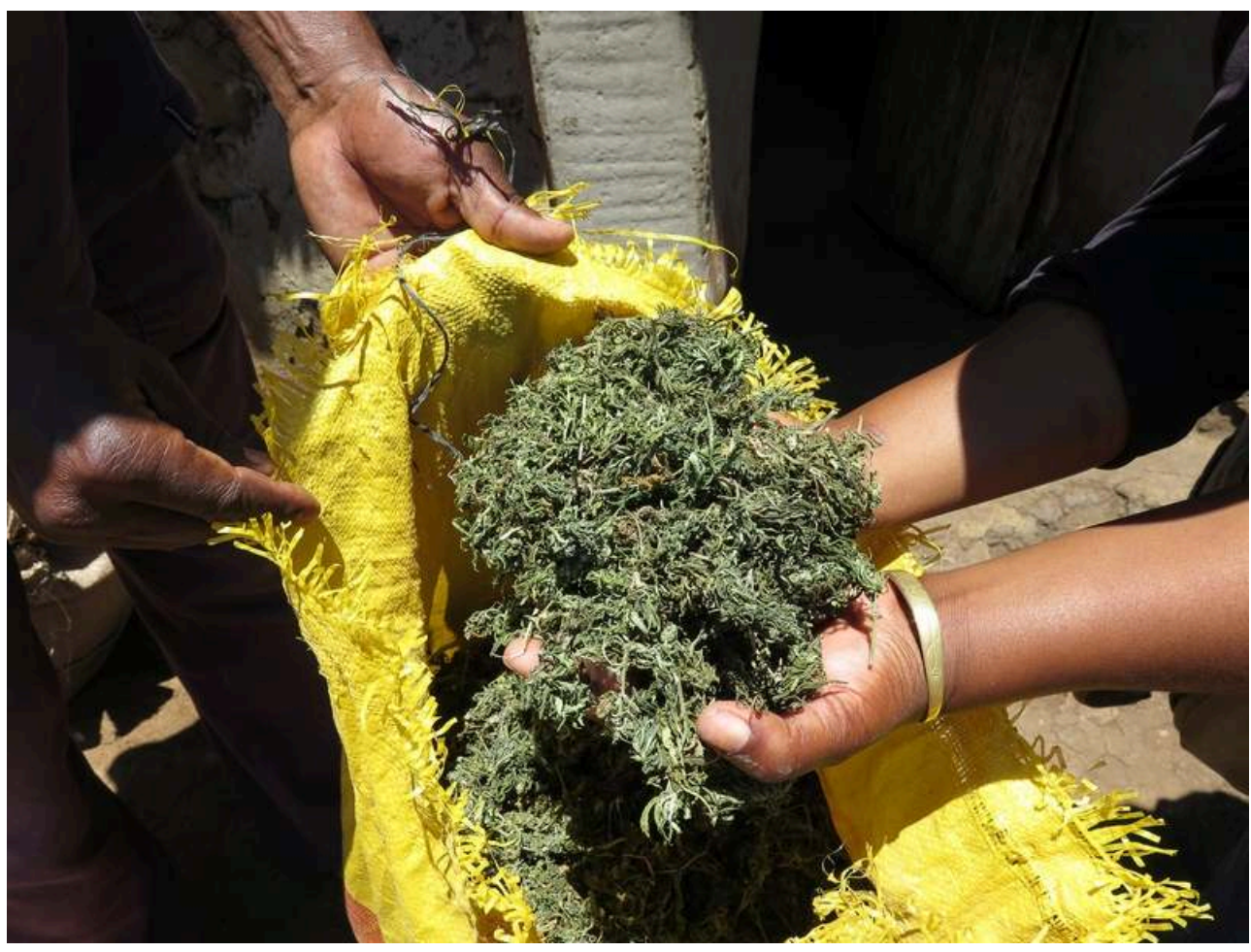

J. Bloomer, December 2015

The cultivation of cannabis in Lesotho can be attributed to a range of physical, social, economic and political factors, although estimating the individual contribution that these factors have made to the cultivation of cannabis is very challenging. Some of the potential causal factors include: the retrenchment of mineworkers from South Africa and the soaring unemployment rates that resulted from this mean that alternative sources of cash need to be found (Boehm, 2003); tighter border and work permit regulations for Basotho entering South Africa have further reduced the opportunities across the border; limited availability of agricultural land in Lesotho could also mean that people are turning to cannabis to increase their returns from the land; declining levels of soil fertility as a result of monocropping practices and overuse that may make the hardy cannabis plant a more suitable option (Nhemachena and Kirsten, 2017); and rising costs associated with the HIV-AIDS epidemic (De Waal and Whiteside, 2003; Mothibi, 2003; Ansell et al., 2016). It is also clear that the role of social institutions, as well as other institutional structures, play a vital role in facilitating this trade.

Cannabis production varies in size and scope, from small isolated patches to large fields that resembles any agricultural cycle with animals to plough the fields and using seeds that are saved from the previous harvest, along with the application of artificial fertiliser. Yields tended to be quite low, perhaps mainly due to a combination of poor seed quality and declining soil fertility. Production is generally rain-fed and typically there are two crops per year. It is also common to intercrop with other food crops, such as maize and beans. Harvesting is frequently a communal activity involving extended 
family or perhaps, for the more wealthy households, paid for on a daily rate (Bloomer, 2009).

Illustration 3 - An elderly woman plucks the leaves and seeds from the stem of the Cannabis sativa plants

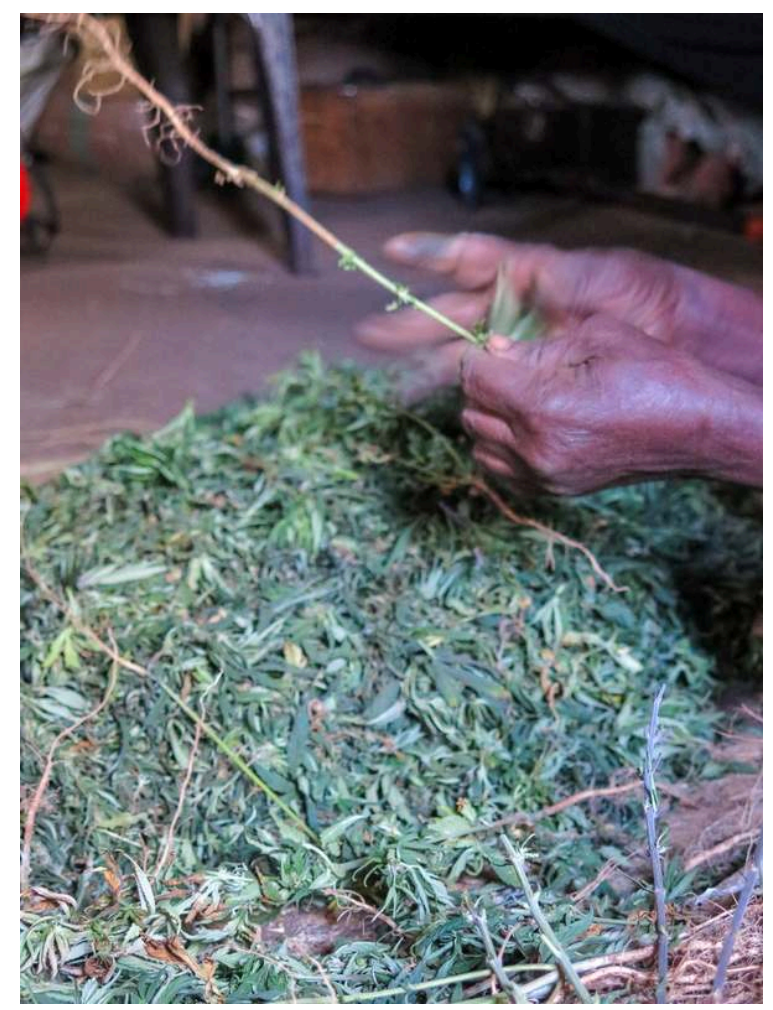

J. Bloomer, December 2015

Without the chieftaincy (and more recently the local government) being complicit in the cannabis trade, or at least not being proactive against it, then it cannot function (Bloomer, 2009). Similarly the community needs to have mechanisms to operate an illegal market and where these have been developed and maintained, cannabis production can occur. The often complicit role of police, as well as border officials and others involved in law enforcement and customs duties, is also crucial to its functioning and reflects how the criminalisation of drugs has generally led to endemic corruption in similar situations elsewhere (Goodhand, 2008; Wolf, 2016). The political turmoil that Lesotho continues to experience in recent years has meant an erosion of human rights, social deprivation and continued economic instability (Thabane, 2016; Southall, 2017). 


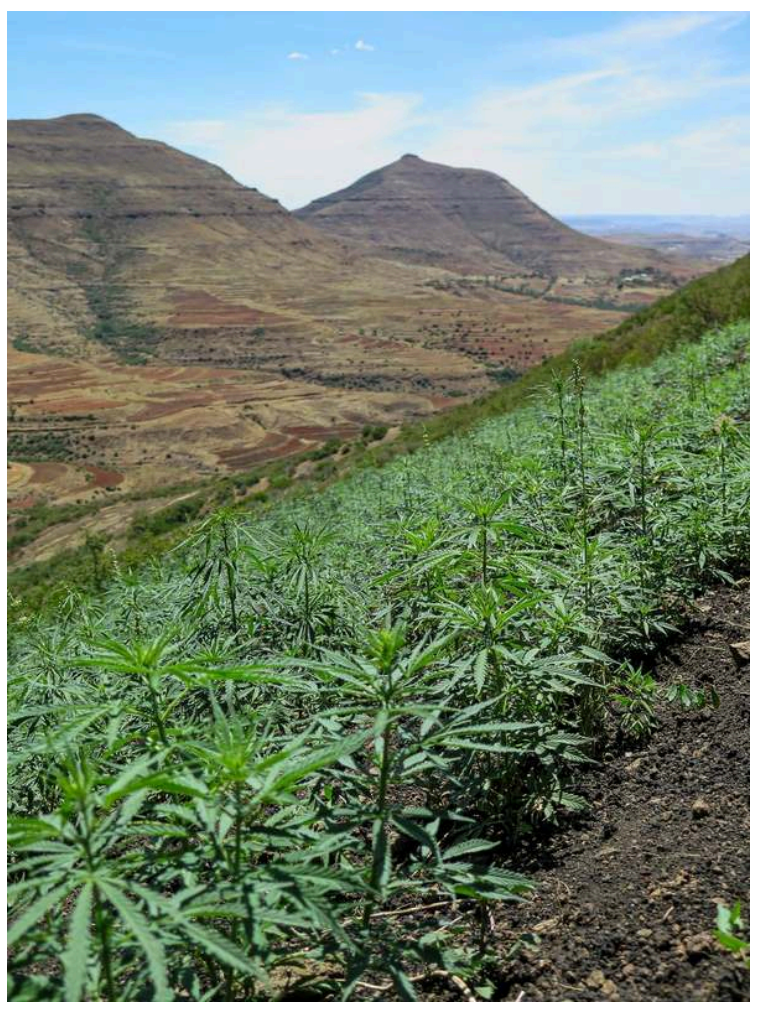

J. Bloomer, December 2015

27 Since no reliable estimates are available for the amount of cannabis cultivated within the country, official figures depend primarily on seizures of cannabis, which vary dramatically from year to year with a very large increase in 2004 but then a fall again to previous levels in 2005. The reasons for such disparities in seizures existing between the years are not easy to identify but point towards an increase in police activity or an increase in volume of trafficking. A seizure of cannabis with an estimated street value of M 2,400,000 was reported (South Africa Press Association, 2006) and a M 500,000 seizure that was being smuggled inside a police vehicle (South Africa Press Association, 2007) $)^{2}$. A note of caution is warranted with regard to media reports and the monetary values of cannabis seized since these values are based on high street-level estimates, which are probably considerably more than the amounts that growers and mid-level smugglers would receive for the product. In its 2006 annual report, the INCB note that in one joint operation involving the South African Police Service (SAPS) and the Lesotho Mounted Police Service (LMPS) during July 2006, 47 tonnes of cannabis were seized (INCB, 2007, p. 38). More recently the Deputy Minister of Health, Manthabiseng Phohleli, was embroiled in a cannabis smuggling operation where 3.5 tonnes of cannabis was discovered in a truck owned by her husband by border officials (Mokhethi and Ntaote, 2018).

\section{Shifting consensus}

28 Cannabis was previously regulated under the Dangerous Medicines Act of 1973 (Government of Lesotho, 1978), which was superseded in 2008 by the Drugs of Abuse Act (Government of Lesotho, 2008) and this move allowed the government to provide 
access to specific drugs for medical and scientific purposes. The International Narcotics Control Board (INCB, 2007) noted the efforts made by the Government of Lesotho to control drug cultivation and comply with the international drug control treaties, however, they also urged the introduction of alternative development programmes, with the assistance of international donors. Just over a decade later, the country has become the first in Africa to change existing legislation and de-criminalise the cultivation of cannabis for medical use. The new law came into effect the following year through the Drug of Abuse (Cannabis) Regulations Act of 2018 and licenses would cost approximately $€ 30,000$ and are issued by the Lesotho Narcotics Board (Phakela, 2018). Soon after, Zimbabwe also followed suit and Malawi has indicated its intentions to do so (Mkhize, 2018). Most recently, South Africa has arguably made significant steps towards de-criminalising cannabis in South Africa when the High Court legalised personal use and cultivation (Gevaaalik, 2018).

Lesotho's move to attract foreign investment in the area of medical cannabis production was reflective of changing attitudes at an international level - both in terms of adhering to international drug controls, as well as an increased emphasis of harm reduction, and a recognition of the potential global value of medical cannabis (Collard, 2018; Lamers, 2018; Tharoor, 2018). Scholars who have been monitoring the shifting opinions and international bodies, however, caution against presuming that legalisation is a foregone conclusion and highlight how fractured international consensus remains (Bewley-Taylor, 2012; Chatwin, 2017; IDPC, 2018). Whether Lesotho remains a key producer of medical cannabis in the region, must surely depend on whether South Africa decides to embark on a similar route and indeed recent legislation appears to be moving exactly in this direction (Nicolson, 2018; Craig, 2019; Joost, 2019; Mafolo, 2019). If this transpires, the competitive advantages that Lesotho's neighbour maintains over the land-locked mountain kingdom would surely also mean that South Africa can dominate in this area of trade as well.

This paper will conclude by examining the recent shift in legislation in Lesotho and critique some of the developmentalist rhetoric surrounding the granting of licenses for medical cannabis and put forward by recent investors. Firstly, given that medical cannabis production occurs in tightly controlled industrial settings, the industry is a fluid one with capital, knowledge and infrastructure able to be relocated anywhere it is legalised. African production settings may influence decision-making of investors and entrepreneurs as they situate their production on the continent and can therefore market their products in much the same way a viticulturist may consider the concept of terroir. Duvall (2016) highlights the importance of genetic diversity in cannabis production on the continent and emphasises how a truly alternative development strategy would allow smallholder farmers on the continent to be granted unconditional access to international markets and also maintain the benefits of crop diversity among the rural poor rather than wealthy bio-prospectors.

31 To-date, approximately seven companies have been awarded a license to produce medical cannabis in Lesotho, with an initial 10-year term for each license (Oleinic, 2019)3. Medi Kingdom was the first company to be granted a license to produce cannabis in Lesotho, with most its initial production destined for Australia. The Prime Minister, Dr Motsoahae Thomas Thabane, officiated at the opening at the company's site in the Maseru District and clearly stated that this moment marked a shift away from illicit production of cannabis that had been "used for wrong purposes without any 
significant benefit to the country or its citizens" (LENA, 2018). The company's website declares that Lesotho is known for growing cannabis easily, "mainly due to its unique topography with mineral rich soils, natural spring waters and high altitudes" (www.medikingdom.com). Furthermore, they anticipate that with the right education and knowledge provided, the industry would undoubtedly "bring huge economic and social benefit [for the] country and Basotho people" (www.medikingdom.com). Yet, through sophisticated growing techniques, such as hydroponics and high quality seed selection, the medical cannabis production facilities are largely removed from their land and environment. A recent investment report, entitled The African Cannabis Report (Prohibition Partners, 2019), declares that "huge opportunities exist up and down the value chain" (2019, p. 56) in the medical cannabis industry in Lesotho in terms of the supply of equipment for industrial growing, as well as nutrients and specialised fertilisers, for example. Similarly, through the necessity of payment for expensive government-issued licenses, smallholder farmers are excluded from the process and production of medical cannabis, although the CEO of Medi Kingdom, James Mathers, has said that in addition to addressing local development needs through the Medi Kingdom Foundation, the company also plans to establish a training academy for local cannabis farmers and thereby ensure they are no longer "exploited by illicit dealers" (Prohibition Partners, 2019, p. 63).

White Sheep Corp, one of the more recent investors to sign up cited the country's progressive attitude towards medical cannabis production and highlighted how the "politically stable constitutional monarchy led by a pro-medical cannabis government with favourable corporate tax rates... and a stable and experienced workforce" (White Sheep Corp, 2019) had encouraged the company to invest there. Although, of course, facilitated by the national government that has long become dependent on attracting foreign investment, the strong colonial overtones surrounding education and development and the potential importance of the medical cannabis industry to the local economy makes one wary of anticipating real benefits for local citizens and points towards the high risk of further wealth capture by national and international political and business elites.

One of the most significant challenges facing the development of the industry, however, appears to be the Basotho-owned companies that are supposed to partner with international investors. Only one-third of the initial 33 Lesotho-based companies that were initially granted free licenses had managed to raise the M 540,000 license fee by the end of 2018. International investors have baulked at grossly inflated requests for partnership fees of up to M 20 million (Motsoeli, 2018). Conscious of the rapidly changing situation elsewhere in the region and there is a recognition that Lesotho may well lose out to other potential markets as they continue to move towards legal production of medical cannabis (Motsoeli, 2018). One investment consultant, Nathan Emery, was one of the few voices sounding caution in relation to the recent developments in the region when he noted that Lesotho is "neither special nor privileged in the global cannabis industry. South Africa has exactly the same climate as Lesotho and an even more varied terrain and most of its areas do not have near the cold and frost that Lesotho has" (Mosabala, 2019).

The developments taking place in Lesotho are perhaps most helpfully viewed through the critical lens of state-sponsored global rushes on land, resources and processes of agrarian transformation that we have seen elsewhere in the region in areas such as 
agri-industrial production, biofuels or extractive industries, for example (Ferguson, 2006; Cotula et al., 2008; Cotula and Vermeulen, 2009a; Cotula and Vermeulen, 2009b; FAO, 2010; Carmody and Taylor, 2016; Kachika, 2017; Makhetha, 2017; Moyo et al., 2019). Hall (2011) cautions against a simplistic view of these acquisitions and highlights their diversity in southern Africa, pointing to a common trajectory, where the "concentration of control of land, labour and value chains (capital) - are rendering the agrarian structure... more like that of settler state like South Africa" (Hall, 2011, p. 207). This may well serve to narrow the contrast between those countries in the region with a history of settler colonialism and those without.

\section{Conclusion}

The developmental impacts of the current transformations taking place in Lesotho are very much in their early stages and clearly much remains to be explored. One area of potential research is assessing the political factors that led to the decision to legalise medical cannabis production, as well as an in-depth analysis of the national and international stakeholders and decision-making behind partnerships. Certainly, it is questionable whether the Lesotho government are acting with due regard for its most vulnerable rural households, who have now long depended on cannabis cultivation to support themselves.

This article framed the transformations taking place against the historical, political and socio-economic background to cannabis cultivation and agricultural transformation in Lesotho. While the nascent legal medical cannabis industry may well provide employment and benefits to some, overall the changes taking place appear far more related to long-standing processes of capital accumulation and elite capture of land, labour and value chains and in its current form is unlikely to deliver lasting socioeconomic change to the majority of the population. In addition, if we consider Lesotho's geographic, economic and political position, the future of the industry must surely be called into question once other countries in the region begin granting licenses for cannabis cultivation.

\section{BIBLIOGRAPHY}

Adams P., Nkuebe M., 2018. Rights in Lesotho: Citizen Views on Police Abuse, Media and Personal Freedom, Gender Equality, Afrobarometer Dispatch [Online], n 242, 11 October. http:// afrobarometer.org/sites/default/files/publications/Dispatches/ab_r7_dispatchno242rights_and_freedoms_in_lesotho.pdf (consulted on 31/05/2019)

African Union, 2013. AU Plan of Action on Drug Control (2013-2017). Addis Ababa, AU. https://au.int/ sites/default/files/pages/32900-file-aupa_on_dc_2013-2017_-_english.pdf (consulted on 21/06/2019) 
Anderson D., Beckerleg S., Hailu D., Klein A., 2007. The Khat Controversy: Stimulating the Debate on Drugs. London, Berg.

Ansell N., Hajdu F., van Blerk L., Robson E., 2016. AIDS-affected Young People's Access to Livelihood Assets: Exploring 'New Variant Famine' in Rural Southern Africa. Journal of Rural Studies, vol. 46, p. 23-34.

Ashton H., 1967 ( $2^{\text {nd }}$ ed.). The Basuto: a Social Study of Traditional and Modern Lesotho. London, Oxford University Press.

Aviles W., 2017. The Drug War in Latin America: Hegemony and Global Capitalism. London, Routledge. Baviskar A., 2004. In The Belly of the River: Tribal Conflicts Over Development in the Narmada Valley. Oxford: Oxford University Press.

Bewley-Taylor D. R., 2012. International Drug Control: Consensus Fractured. Cambridge, Cambridge University Press.

Bloomer J., 2009. Using a Political Ecology Framework to Examine Extra-Legal Livelihood Strategies: a Lesotho-Based Case Study of Cultivation of and Trade in Cannabis. Journal of Political Ecology, vol. 16, n 1, p. 49-69.

Boehm C., 2003. The Social Life of Fields: Labour Markets and Agrarian Change in Lesotho. Paideusis, vol. 3, p. 1-20.

Braun Y. A., 2015. Interrogating Large-scale Development and Inequality in Lesotho: Bridging Feminist Political Ecology, Intersectionality, and Environmental Justice Frameworks. In Buechler S., Hanson A.M.S., 2015, A Political Ecology of Women, Water and Global Environmental Change, London, Routledge, p. 19-37.

Bybee A.N., 2012. The Twenty-First Century Expansion of the Transnational Drug Trade in Africa. Journal of International Affairs, vol. 66, $\mathrm{n}^{\circ} 1$, p. 69-84.

Carmody P., 2011. The New Scramble for Africa. Cambridge, Polity Press.

Carmody P., Taylor D., 2016. Globalization, Land Grabbing, and the Present-day Colonial State in Uganda: Ecolonization and its Impacts. The Journal of Environment \& Development, vol. 25, $\mathrm{n}^{\circ} 1$, p. $100-126$.

Carrier N., Klantschnig G., 2012. Africa and the War on Drugs. London, Zed Books.

Carrier N., Klantschnig G., 2016. Illicit Livelihoods: Drug Crops and Development in Africa. Review of African Political Economy, vol. 43, n 148, p. 174-189.

Carrier N., Klantschnig G., 2018. Quasilegality: khat, cannabis and Africa's drug laws. Third World Quarterly, vol.39, n², p. 350-365.

Casalis E., 1889. My Life in Basutoland. London, Religious Tract Society.

Chatwin C., 2017. UNGASS 2016: Insights from Europe on the Development of Global Cannabis Policy and the Need for Reform of the Global Drug Policy Regime. International Journal of Drug Policy, vol. 49, p. 80-85.

Chaves-Agudelo J. M., Batterbury S. P., Beilin R., 2015. "We Live From Mother Nature” Neoliberal Globalization, Commodification, the "War on Drugs," and Biodiversity in Colombia Since the 1990s. SAGE Open, vol. 5, n 3, p. 1-15.

Chouvy P.-A., 2010. Opium: Uncovering the Politics of the Poppy. London, I.B. Tauris. 
Chouvy P.A., Macfarlane J., 2018. Agricultural Innovations in Morocco's Cannabis Industry. International Journal of Drug Policy, vol. 58, p. 85-91.

Cilliers J., 2001. Regional Conflict and Poverty in Southern Africa. Institute of Security Studies, Paper presented at a Southern African Regional Poverty Network (SARPN) conference held at the Human Sciences Research Council, 26 April, Pretoria.

Collard G., 2018. FastForward Investee Nuuvera Signs Lesotho Cannabis Offtake Agreement. London South East [Online], 26 February. http://www.lse.co.uk/AllNews.asp? code=dsiznod3\&headline=FastForward_Investee_Nuuvera_Signs_Lesotho_Cannabis_Offtake_Agreement (consulted on 31/05/2019)

Cotula L., Dyer N. Vermeulen, S., 2008. Fuelling Exclusion? The Biofuels Boom and Poor People's Access to Land. London, International Institute for Environment and Development (IIED).

Cotula L., Vermeulen S., 2009a. Land Grabs in Africa: Can the Deals Work for Development? London, International Institute for Environment and Development (IIED).

Cotula L., Vermeulen, S., 2009b. Deal or no Deal: The Outlook for Agricultural Land Investment in Africa. International Affairs, vol. 85, nº 6, p. 1233-1247.

Craig N., 2019. Medical Cannabis Use is Now Legal. Independent Online, 26 May. https:// www.iol.co.za/sunday-tribune/news/medicinal-cannabis-use-is-now-legal-24102387 (consulted on $31 / 05 / 2019)$

De Waal A., Whiteside A., 2003. New Variant Famine: AIDS and Food Crisis in Southern Africa. The Lancet, vol. 362, n 9391, p. 1234-1237.

Dimova M., 2016. 'The First Dragon to Slay': Unpacking Kenya's War on Drugs. Review of African Political Economy, vol. 43, n 148 , p. 227-242.

Du Toit B. M, 1996. Pot By Any Other Name is Still... A Study of the Diffusion of Cannabis. South African Journal of Ethnology, vol. 19, $\mathrm{n}^{\circ}$ 4, p. 127-135.

Du Toit B. M., 1980. Cannabis in Africa: A Survey of its Distribution in Africa, and a Study of Cannabis Use and Users in Multi-ethnic South Africa. AA Bolkema.

Duvall C.S., 2016. Drug Laws, Bioprospecting and the Agricultural Heritage of Cannabis in Africa. Space and Polity, vol. 20, $\mathrm{n}^{\circ}$ 1, p. 10-25.

Ellenberger D.F., MacGregor J.C., 1912. History of the Basuto: Ancient and Modern, London, Craxton. Ellis S., 2009. West Africa's International Drug Trade. African Affairs, vol. 108, n 431, p. 171-196. FAO, 2010. Principles for Responsible Agricultural Investment That Respects Rights, Livelihoods and Resources. Food and Agricultural Organisation Discussion Note, 25 January, Rome, FAO.

Ferguson J., 2006. Global Shadows: Africa in the Neoliberal World Order. Durham, Duke University Press.

Gastrow P., 2003. Mind-Blowing: The Cannabis Trade in Southern Africa. Unpublished paper, Cape Town, Institute for Security Studies.

Gay J., Hall D., 2000. Poverty and Livelihoods in Lesotho, 2000: More than a Mapping Exercise. Maseru, Sechaba Consultants.

Gevaaalik S., 2018. Is Dagga Legal in South Africa? Gevaaalik.com, 18 September. https:// gevaaalik.com/is-dagga-legal-in-south-africa-18-september-2018 (consulted on 23/06/2019) 
Gill,S., 1993. A Short History of Lesotho: From the Late Stone Age Until the 1993 Elections. Morija, Morija Museum and Archives.

Goeke M., 2016. Political Stability and Peace Through Party Engineering: The Case of Lesotho. Politikon, vol. 43, n 3, p. 293-309.

Goodhand J., 2008. Corrupting or Consolidating the Peace? The Drugs Economy and Post-conflict Peacebuilding in Afghanistan. International Peacekeeping, vol. 15, n 3, p. 405-423.

Government of Lesotho, 1978. The Laws of Lesotho, Volume XVIII. Maseru, Government of Lesotho Printer.

Government of Lesotho, 2008. Drugs of Abuse Act 2008.

Maseru, Government of Lesotho [Online] https://lesotholii.org/ls/legislation/act/5/

DRUGS\%200F\%20ABUSE\%20ACT\%202008.pdf (consulted on 24/06/2019)

Guillarmod A.J., 1971. Flora of Lesotho. Hemsbach, Krebs.

Hall J., 2003. Africa at Large: Farmers Find Marijuana the Most Lucrative Cash Crop. Oslo, The Norwegian Council for Africa.

Hall R., 2011. Land Grabbing in Southern Africa: The Many Faces of the Investor Rush. Review of African Political Economy, vol. 38, n 128, p. 193-214.

Hall T., 2012. Geographies of the Illicit: Globalization and Organised Crime. Progress in Human Geography, vol. 37, n 3, p. 366-385.

Harrison R., 2005. The Weed that Feeds Tiny Swaziland. Independent Online, 13 June. https:// www.iol.co.za/news/africa/the-weed-that-feeds-tiny-swaziland-243620 (consulted on $31 / 05 / 2019)$

Heggelund G., 2004. Environment and Resettlement Politics in China: The Three Gorges Project. Aldershot, Ashgate.

Heyman J., 1999. States and Illegal Practices. Oxford, Berg Press.

Hoag C., 2019. "Water is a Gift that Destroys": Making a National Natural Resource in Lesotho. Economic Anthropology [Online], vol. 6, p. 183-194. https://doi.org/10.1002/sea2.12149

IDPC, 2018. Taking Stock: A Decade of Drug Policy. International Drug Policy Consortium. http:// files.idpc.net/library/Shadow_Report_FINAL_ENGLISH.pdf (consulted on 31/05/2019)

INCB, 2004. Annual Report 2003. Vienna, International Narcotics Control Board.

INCB, 2007. Annual Report 2006, Vienna, International Narcotics Control Board.

IRIN News/The New Humanitarian, 2006. Swaziland: Marijuana - Hope for the Homeless. United Nations Integrated Regional Information Networks (IRIN) |Online], http://www.irinnews.org/ report.aspx?reportid=58025 (consulted on 31/05/2019)

Joost R., 2019. Dabbling in Weed Could be Good for Democracy. Daily Maverick [Online], 10 April, https://www.dailymaverick.co.za/article/2019-04-10-dabbling-in-weed-could-be-good-fordemocracy/ (consulted on 31/05/2019)

Kachika T., 2017. Landgrabbing in Africa: A Review of the Impacts and the Possible Policy Responses. Oxford, Oxfam international.

Kepe T., 2003. Cannabis Sativa and Rural Livelihoods in South Africa: Politics of Cultivation, Trade and Value in Pondoland. Development Southern Africa, vol. 20, n 5, p. 605-615. 
Khumalo K., 2018. Lesotho Emerges as a Marijuana Investor Darling. Independent Online, 12 December. https://www.iol.co.za/business-report/economy/lesotho-emerges-as-a-marijuanainvestor-darling-18483413 (consulted on 31/5/2019)

Kings S., 2016. High and Dry: South Africa Leaves Lesotho Parched, Climate Home News [Online], 6 October. https://www.climatechangenews.com/2016/10/06/high-and-dry-african-droughtleaves-lesotho-parched/ (consulted on 31/05/2019)

Klantschnig G., Dimova M., Cross H., 2016. Africa and the Drugs Trade Revisited. Review of African Political Economy, vol. 43, $\mathrm{n}^{\circ}$ 148, p. 167-173.

Labrousse A., 2003. The Development of Cannabis Production. African Geopolitics, vol. 10, p. 267-277.

Kobisi K., 2005. A Preliminary Checklist of the Plants of Lesotho, Southern African Botanical Diversity Network (SABONET). Pretoria, SABONET, Report n 34.

Lamers M., 2018. Lesotho Attracts Another Major Medical Cannabis Investment. Marijuana Business Daily [Online], 21 March. https://mjbizdaily.com/lesotho-attracts-another-majormedical-cannabis-investment/ (consulted on 31/05/2019)

Laniel L., 1998. Cannabis in Lesotho: A Preliminary Study. Management of Social Transformations [Online], Discussion Paper n ${ }^{\circ}$ 34, Website: http://www.unesco.org/most/dslaniel.htm (consulted on $31 / 05 / 2019$ )

Laniel L., 2001. Drugs in Southern Africa: Business as Usual. International Social Science Journal, vol. 169 , p. 407-414.

Laudati A. A., 2016. Securing (In)Security: Relinking Violence and the Trade in Cannabis Sativa in Eastern Democratic Republic of Congo. Review of African Political Economy, vol. 43, $n^{\circ} 148$, p. 190-205.

Leggett T., 2002. Rainbow Vice: The Drugs and Sex Industries in South Africa. London, ZED Books.

LENA, 2018. PM Launches Cannabis Cultivator. Lesotho News Agency [Online], 11 December. https://www.gov.ls/pm-launches-cannabis-cultivator/ (accessed 26/06/2019)

LHWP, 1996a. Baseline Epidemiology and Medical Services Survey, Phase 1B - A Comparison of the Socioeconomic Surveys of Phase 1A and 1B. Maseru, Lesotho Highlands Development Authority.

LHWP, 1996b. Baseline Epidemiology and Medical Services Survey, Phase 1B - Knowledge, Attitudes and Behaviour: Mental Health and Substance Abuse, Final Report, Task 2, Maseru, Lesotho Highlands Development Authority.

LHWP, 1996c. Resettlement and Development Study - Main Report (Task 2, Volume 2), Maseru, Lesotho Highlands Development Authority.

LHWP, 1997. Environmental Impact Assessment, Phase 1B - Main Report, Maseru, Lesotho Highlands Development Authority.

Mafolo K., 2019. Expo Unpacks Cannabis Licensing in South Africa. Daily Maverick [Online], 9 April. https://www.dailymaverick.co.za/article/2019-04-09-expo-unpacks-cannabis-licensing-in-southafrica/ (consulted on 31/05/2019)

Magubane B., Safa H.I., Du Toit B. M., 1975. The Native Reserves (Bantustans) and the Role of the Migrant Labor System in the Political Economy of South Africa. The Hague, Monton Publishers.

Makheth E. L., 2017. Small Scale Artisanal Diamond Mining and Rural Livelihood Diversification in Lesotho. Doctoral dissertation, Pretoria, University of Pretoria. 
Mansfield D., 2016. A State Built on Sand: How Opium Undermined Afghanistan. London, Hurst.

McCurdy S., Kaduri P., 2016. The Political Economy of Heroin and Crack Cocaine in Tanzania. Review of African Political Economy, vol. 43, n 148, p. 312-319.

McSweeney K., Wrathall D. J., Nielsen E. A., Pearson Z. 2018. Grounding Traffic: The Cocaine Commodity Chain and Land Grabbing in Eastern Honduras. Geoforum, vol. 95, p. 122-132.

Meehan P., 2011. Drugs, Insurgency and State-building in Burma: Why the Drugs Trade is Central to Burma's Changing Political Order. Journal of Southeast Asian Studies, vol. 42, n 3, p. 376-404.

Mkhize V., 2018. Marijuana, Mountains and Money: How Lesotho is Cashing in. BBC News [Online], 28 November. https://www.bbc.com/news/world-africa-46288374 (consulted on 31/05/2019)

Mokheti S., Ntaote B., 2018. Lesotho: Deputy Health Minister Caught up in Attempt to Smuggle R5m Worth of Dagga to SA. Daily Maverick [Online], 27 February. https://

www.dailymaverick.co.za/article/2018-02-27-lesotho-deputy-health-minister-caught-up-inattempt-to-smuggle-r5m-worth-of-dagga-to-sa/ (consulted on 31/05/2019)

Mosabala T., 2019. Cannabis: Lesotho's New Diamond But..., Centre for Investigative Journalism [Online], 8 January. https://lescij.org/2019/01/08/cannabis-lesothos-new-diamond-but/ (consulted on 25/06/2019)

Mothibi M., 2003. The Impact of HIV/AIDS on Livelihoods in Lesotho: Phase 1 - Mafeteng. Livelihoods Recovery Through Agriculture Programme (LRAP), Discussion Paper $n^{\circ}$ 3. Maseru, CARE Lesotho.

Motsoeli N., 2018. Locals in Danger of Losing Out on Lucrative Cannabis Industry, Lesotho Times [Online], 13 December, https://www.pressreader.com/@nickname12374492/ csb_DjQln8g5kTNva5wAH9xJzHO8Rnki9cYckduOy-SWUaJnLanJZLdVog2MxXoLFlKJ (consulted on 25/06/2019)

Moyo S., Jha P., Yeros P. 2019. The Scramble for Land and Natural Resources in Africa. In Moyo S., Jha P., Yeros P., 2019. Reclaiming Africa. Advances in African Economic, Social and Political Development. Singapore, Springer.

Muñoz-Mora J. C., Tobón S., d'Anjou J. W., 2018. The Role of Land Property Rights in the War on Illicit Crops: Evidence From Colombia. World Development, vol. 103, p. 268-283.

Mwangi O. G., 2016. State Fragility and Electoral Reforms in Lesotho. In Olowu D., Chanie P., 2016, State Fragility and State Building in Africa. Springer, Cham, p. 209-232.

Nhemachena C. R., Kirsten J., 2017. A Historical Assessment of Sources and Uses of Wheat Varietal Innovations in South Africa. South African Journal of Science. vol. $113 n^{\circ}$ 3-4, p. 1-8.

Nhemachena C., Matchaya G., Nhlengethwa,S., 2017. Agricultural Growth Trends and Outlook for Lesotho. ReSAKSS-SA Annual Trends and Outlook Report 2016 [Online]. International Food Policy Research Institute (IFPRI), International Water Management Institute (IWMI). https:// www.resakss.org/sites/default/files/ReSAKSS-SA\%20-\%20ATOR\%20-\%202016\%20\%20high\%20res\%20with\%20crop\%20marks\%20(002).pdf (consulted on 31/05/2019)

Nicolson G., 2018. What next? 'We Won the Battle on Cannabis', But the War Isn't Over. Daily Maverick [Online], 19 September. https://www.dailymaverick.co.za/article/2018-09-19-whatnext-we-won-the-battle-on-cannabis-but-the-war-isnt-over/ (consulted on 31/05/2019)

Nordstrom C., 2007. Global Outlaws: Crime, Money and Power in the Contemporary World. Berkeley, University of California Press.

Oellermann I., 2007. Huge drug haul. News 24 [Online], 12 November. https://www.news24.com/ Archives/Witness/Huge-drug-haul-three-appear-20150430 (consulted on 23/06/2019) 
Oleinic A., 2019. Halo Labs Enters African Cannabis Market Through Bophelo Acquisition. Benzinga [Online], 18 June. https://www.benzinga.com/markets/cannabis/19/06/13937779/halolabs-enters-africa-cannabis-market-through-bophelo-acquisition (consulted on 24/06/2019)

Panos Institute, 1997. Mountain Voices, Transcripts for interviews. Available at Website: http:// www.mountainvoices.org/lesotho.asp.html (accessed 31/05/2019).

Phakela M., 2018. 500 k for Medical Marijuana License, Lesotho Times [Online], 2 June. http:// lestimes.com/500k-for-medical-marijuana-licence/ (consulted on 31/05/2019).

Pherudi M., 2018. The Assassination of Military Commanders in Lesotho: Triggers and Reactions. Journal for Contemporary History, vol. 43, n 2, p. 117-133.

Prohibition Partners, 2019. The African Cannabis Report [Online], March. https:// prohibitionpartners.com/reports/\#african-cannabis-report (consulted on 24/06/2019)

Rincón-Ruiz A., Kallis G., 2013. Caught in the Middle: Colombia's War on Drugs and its Effects on Forest and People. Geoforum, vol. 46, p. 60-78.

Rothberg A., 2017. Thoughts as we consider the legalisation of cannabis in South Africa, South African Journal of Child Health. vol. 11, $n^{\circ}$ 4, p. 153.

South Africa Press Association, 2006. Dagga Bust at Lesotho Border. News 24 [Online], South African Press Association, 22 December. http://www.news24.com/News24/South_Africa/News/ 0,9294,2-7-1442_2048094,00.html (consulted on 02/05/2007)

South Africa Press Association, 2007. Police Seize Cop Car Transporting Dagga. Mail and Guardian Online, South African Press Association. http://www.mg.co.za/articlePage.aspx?area=/ breaking_news/breaking_news__national/\&articleid=298173 (consulted on 02/05/2007)

Schiller R., Foy, K. 2017. Cartel Hit Hard as € $37.5 \mathrm{~m}$ Drug Shipment Seized by Gardai at Port. The Herald [Online], 21 January. https://www.herald.ie/news/cartel-hit-hard-as-37-5m-drugshipment-seized-by-gardai-at-port-35385986.html (consulted on 23/06/2019)

Scudder T., 2006. The Future of Large Dams: Dealing With Social, Environmental, Institutional and Political Costs. London, Earthscan.

Southall R., 2017. Why Lesotho's in Such a Mess and What Can be Done About it. The Conversation [Online], 19 June, https://theconversation.com/why-lesothos-in-such-a-mess-and-what-can-bedone-about-it-79678 (consulted on 31/05/2019)

Snyder R., Duran-Martinez A., 2009. Does Illegality Breed Violence? Drug Trafficking and StateSponsored Protection Rackets. Crime, Law and Social Change, vol. 52, n 3, p. 253-273.

Su X., 2018. Fragmented Sovereignty and the Geopolitics of Illicit Drugs in Northern Burma. Political Geography, vol. 63, p. 20-30.

Suckling C. A., 2016. Chain Work: The Cultivation of Hierarchy in Sierra Leone's Cannabis Economy. Review of African Political Economy, vol. 43, issue 148, p. 206-226.

Thabane M. 2016. Lesotho: Rule by Force, Intimidation and Fear. The Patriot [Online], 6 July, http://www.thepatriot.co.bw/analysis-opinions/item/2795-lesotho-rule-by-force,-intimidationand-fear.html (consulted on 31/05/2019)

Thabane M., 2000. Shifts From the Old to New Social and Ecological Environments in the Lesotho Highlands Water Scheme: Relocating Residents of the Mohale Dam Area. Journal of Southern Africa. vol. $26, \mathrm{n}^{\circ} 4$, p. 633-653 
Tharoor A., 2018. US Corp Cashes in as Lesotho Becomes the First African Country to Legalise Cannabis Cultivation. Talking Drugs [Online], 7 February. https://www.talkingdrugs.org/lesothocannabis-legalisation-restricted (consulted on 31/05/2019)

Tinti P., Reitano T., 2018. Migrant, Refugee, Smuggler, Saviour. Oxford, Oxford University Press.

Turner S. D., 2001. Livelihoods in Lesotho. Maseru, CARE Lesotho.

UNODC, 2004. Maroc. Enquête sur le Cannabis. Vienna, United Nations Office on Drugs and Crime.

UNODC, 2007. Cannabis in Africa: An Overview. Vienna, United Nations Office on Drugs and Crime.

Wolf S., 2016. Drugs, Violence, and Corruption: Perspectives From Mexico and Central America. Latin American Politics and Society, vol. 58, $\mathrm{n}^{\circ}$ 1, p. 146-155.

White Sheep Corp., 2019. White Sheep Breaks Ground on Licensed Cannabis Facility in Lesotho, Africa, White Sheep Corp. Press Release [Online], 28 May. https://whitesheepcorp.com/white-sheepbreaks-ground-on-licensed-cannabis-facility-in-lesotho-africa/ (consulted on 31/05/2019)

\section{NOTES}

1. Several different terms for cannabis appear in English literature as well as regional language variations, all referring to the Cannabaceae family. North American literature favours the name marijuana whilst cannabis is mainly used in Europe and among UN agencies. Within the southern African context, dagga (pronounced dac-ha) is the most common term, although specific languages still have their own translations. In Southern Sotho, for example, the formal term is matekoane. This paper will use cannabis, an abbreviation of the species Cannabis sativa, as the default name, dagga and matekoane will also be used when discussing the southern African and Lesotho contexts and in the presentation of the research findings. Hemp is the common name for Cannabis strains cultivated for non-drug use.

2. Maloti (M) is the currency in Lesotho. The exchange rate on $31^{\text {st }}$ May 2019 was 1 Lesotho Loti to $€ 0.06$ (Website: http://www.xe.com). As the Lesotho Maloti and South African Rand (R) are linked at the same rate, the same rate of exchange is used when calculating values present in Rand.

3. As of March 2019, these companies were: Medi-Kingdom (majority owned by UK founder with local partners); Medigrow Lesotho PTY (10 \% acquired by Supreme Cannabis from Canada); Verve Dynamics (approximately $30 \%$ ownership by Canadian-based Aphria); Daddy-Cann (100\% acquired by Canopy Growth from Canada); Pharmaceuticals Development Corp (PDC) (Prohibition Partners, 2019, p. 59). In May 2019 White Sheep Corp began constructing its facilities (White Sheep Corp, 2019), while in June 2019 Halo Labs Ltd acquired the Lesotho-based Bophelo Bioscience and Wellness (Oleinic, 2019).

\section{ABSTRACTS}

This article examines the evolving historical, geopolitical and economic context of cannabis cultivation in Lesotho. The article will present a brief history of cannabis cultivation in Lesotho, before assessing the possible impacts of recent changes in policy and legislation, following recent 
the announcement by the Lesotho government of production under license for companies cultivating medical cannabis. The article will conclude by critiquing the development potential of this recent move, against evolving policy debates in southern Africa.

\section{INDEX}

Keywords: cannabis, livelihood, development, Lesotho, legalization

\section{AUTHOR}

\section{JULIAN BLOOMER}

Julian Bloomer, Julian.Bloomer@mic.ul.ie, is an Assistant Lecturer in Human Geography, Department of Geography, Mary Immaculate College (University of Limerick), Limerick City, Ireland. He recently published

- Bloomer J., (forthcoming). The Only Honest Thief: Critiquing the Role of Human Smugglers. In Morrissey J. (ed.), Haven: Intervening for Human Security in the Mediterranean Crisis. London, Edward Elgar Publishing.

- Bloomer J., 2009. Using a Political Ecology Approach to Extra-legal Rural Livelihoods: a Lesothobased Case Study of Cultivation of and Trade in Cannabis. Journal of Political Ecology [Online], vol. 16, n 1, p. 49-69 DOI: https://doi.org/10.2458/v16i1.21691

- Bloomer J., 2004. Divided We Fall: Towards an Understanding of Community Risk Assessment: A Case Study from the Lao PDR. International Journal for Mass Emergencies and Disasters, vol. 24, $\mathrm{n}^{\circ} 3$, p. 87-108. 